\title{
Analyze the Competitiveness of Iran in the Aluminum Export with the Use of Analyze the Share Shift Index and Trademapping Index
}

\author{
Saeed Moazemi Goodarzi ${ }^{1} \&$ Ebrahim Ali Razini $^{2}$ \\ ${ }^{1}$ M. A of Executive MBA, Department of Management, Karaj Science and Research Branch, Islamic Azad \\ University, Karaj, Iran \\ ${ }^{2}$ Assistant Prof, Faculty of management and accountancy, Islamic Azad University Karaj Branch, Karaj, Iran \\ Correspondence: Saeed Moazemi Goodarzi, M. A of Executive MBA, Department of Management, Karaj \\ Science and Research Branch, Islamic Azad University, Karaj, Iran. Tel: 98-9124-086-880. E-mail: \\ Moazemi.Saeed@gmail.com
}

Received: July 17, 2016

Accepted: July 31, $2016 \quad$ Online Published: September 3, 2016

doi:10.5539/mas.v10n12p177

URL: http://dx.doi.org/10.5539/mas.v10n12p177

\begin{abstract}
Due to the importance of non-oil export in the country, the aim of this research is the study and analysis of competitiveness Iran's in aluminum export to world markets in the period of 2005 to 2014 with the use of share shiftanalysis index and trademapping index. The analysis of share shift index is a standard of determine the competitiveness include the three effect of competitiveness, structural effect and effect of reaction to changing global demand. Sum of these three works has been used for calculate the total number of competitiveness in the present research and following that analyze the aluminum export. The results show that share of Iran in the aluminum export in the global markets had been increased except between 2013 and 2014. Moreover, these evidences show that structural effect had been the only reason of increase the advantage among components of share shiftanalysis index two effect of competitiveness and reaction to change in the global demand cause to had been reduced the advantage. In other words, the aluminum industry had been progressed in term of structural but it had been regressed in terms of the competitiveness effect and effect of reaction to change in global demand.
\end{abstract}

Keywords: competitiveness, competitive advantage, export, aluminum industry

\section{Introduction}

Nowadays the sector of foreign trade are attended as one of the most important economic sectors in all countries, especially developing countries. In fact, international interactions and exchanges are part of the basic and Inseparable conditions of development. In today's world no country can not fulfill the all needs of its community without products and services of other countries. If this power has existed in the countries is not affordable economically.

As a result the issue of exchange the goods and services between countries is offered based on comparative and competitive advantages. In fact International trade exchanges is inseparable part of each country's economy, and this with globalization the economic takes the more serious form to itself increasingly. Present research evaluates the competitive advantage of Iran in the aluminum export to global markets in the period of 2005 to 2014 with the use of analyze the share shift index and trademapping.

Given that aluminum is strategic goods commodity in the world and it has the high relative user therefore, the development of competitiveness in this industry can lead to increased the employment and development of non-oil export.On the one hand, encounter with phenomenon of market globalization and membership in the global trade organization will be entail the acceptance of requirements for industry of Iran.

The importance of research is in that analyze the competitiveness that it is one of the measuring indexes of competitive advantage and competitiveness dynamically and it is evaluated in the industry level and most of the done studies in related to the competitiveness and competitive advantage has been conducted with the use of other measurement indexes in the agency and industry levels in Iran and since, index of share shift analysis and mapping index has been used in a few cases.

Many studies have been conducted in the field of comparative advantage and competitiveness that in the 
following is pointed to important of them:

Mahmoud Mahmoud Zadeh et al. (2012) conducted the competitiveness of Iran in the medicines export with the use of share shift analysis index during the 2002 to 2010. The results show that Iran in the medicine export in global markets had been increasing trend except in some years. In addition, evidences show that between components of share shift analysis index, effect of reaction to change in global demand had been the only reason of increasing comparative advantage. In other words, the medicine industry of Iran had been progressed in term of reaction to change in global demand, but it had been regressed in terms of the competitiveness effect and structural effect.

Franyk and Kamryk (2006) evaluated the competitiveness of sugar in Croatia during the period of 1995 to 2003 by using domestic resource cost index. According to research results, the production of sugar in Croatia is not competitive at the international level. One of the characteristics of foreign trade in field sugar was high exports of that until 2003. Severe change in the policies related to sugar in Europe union, according to rules of global trade organization led to reduction of the sugar price that it impressed the sugar industry of Croatia.

Welch and Lyfvrd (2007) evaluated the amount of competitiveness of America based on revealed comprative advantageindex during the period of 1989 to 2005. The results show that America is in lower position in competition with major producers of cotton yarn (India, China, Turkey and Pakistan). Based on the revealed comparative advantage in the field of share market of cotton yarn export, the United States is after China, India, Turkey and Pakistan. Remove the trade barriers leads to pressure on competitive abilities of loom producers of United States the extent that they put under pressure of quotas and tariffs.

Nick Mohammed and Jacob (2008) evaluated the amount of competitiveness of electric industry and Malaysian electronics based on constant share of market index and revealed comparative superiority with four countries: America, Singapore, Japan and Hong Kong during the period of 1990 to 2004. The results show that in the period of 1990 to 1994, electric export and electronic of Malaysia had been competitive compared to the four countries: America, Singapore, Japan and Hong Kong.

In the years of 1995 to 1999 and 2000 to 2004 results of stable market share show that increase the electric export and electronic Malaysia but this increase had not been due to competition in the market but also it had been because of the structural effect caused by increase of global import. Results of revealed comparative advantage show that electric and electronic products only in America's market had been high performance. Indonesia had been involved with Singapore's market and China had been involved with Hong Kong's market. Electric and electronic exports of Malaysia to the world generally had been relative superiority compared to competitors of Indonesian, Thai and Chinese.

Jack Vuze and Rybakvaz (2010) analyzed the competition in the clothes and textile industry of Lithuania in years of 2006 and 2007 and 2008 by index of stable market share analysis and revealed comparative advantage. Countries under study, are countries of Europe Union member. About the efficiency of clothes and textile industry, Lithuania is ranked in the category of countries that are less competitive.

According to results of stable market share index, Lithuania has maintained its export in field of clothes and textile among China, Italy, Germany, Turkey, India, Estonia, Poland, Hungary, Slovakia and Latvia and it had been a little reduction in year of 2008. According to results of revealed comparative advantage index during the studied years clothes and textile industry of Lithuania has revealed comparative advantage greater than one that it shows relative superiority in the production of these products.

\section{Development of Theory and Hypotheses}

Aluminum is a chemical element that it has symbol of $\mathrm{AL}$ and atomic number of 13 in the periodic table. Aluminum is the silver and flexible element often is find as the bauxite ore and it has resistance against of oxidation also it has significant weight and strength. The weight of aluminum is one-third the of steel or copper almost, and it is a flexible malleable metal and it bends easily also it is also very lasting and resistant against of corroded.

Friedrich Wöhler believed to pure aluminum generally (Latin: Alum, Alumen) but this metal two years earlier was obteined by Hans Christian Ørsted, Danish Chemist and physicist. Aluminum is basic and necessary material in the dynamic global economy with multiple uses. Strength, conductivity, resistance against of corrosion, ability to recover and light weight of this metal is appropriate that quite for remove the diverse needs and in terms of complex technology of today's world.

Most importantly, aluminium can be considered the substance with highest environmental sustainability in the earth that every day it finds more sensitive. This metal can be recovered with only $5 \%$ of primary energy. 
Recycled aluminum has same quality as primary aluminum. Now aluminum use in the production of home appliances, door and window, building facades, bridge, ship, aircraft, car, machinery, aerospace industry, military industry, electricity, etc., and for this reason it is a strategic substance in the world.

In terms of organization for economic co-operation and development (OECD) level (quality) of the goods and services of country that it can gain the global markets demand in free market conditions and it fulfill the various levels of this demand and at the same time by this instrument it increases the real income of citizenry in the long-term, it is reflection of the competitiveness level of that country. Krugman (1987) introduced the theory of dynamic comparative advantage with this idea that advantage is adventitious and along with the change in the stock of factors and technology.

Also Krugman expressed that efficiency in the production, expertise and skills are among the factors that are cause to changes in comparative advantage. Finally competitive advantage was bring up by Porter (1985) with this concept that competitive advantage means the features and resources that it enables an organization until surpasses from competitors in aindustry. In other words, competitive advantage is differentiation of a company in the one or more factors that it allows to the company to better service and creating more value for the customer and therefore better performance compared to competitors (Chaharbaghi \& lynch, 1999).

Competitive advantage theory (Means the possibility of obtain the appropriate and stable position in the global market) is one of the new theories of advantages that it has been provided for explain the international trade. Competitive advantage is a situation that it enables a agancy provides the product with lower cost and higher quality with higher efficiency and use the superior methods and it provides the more profits for the agancy in competition with competitors. According to this theory how to use the resources and amount of access to that has determinative role in the determining competitive advantage.

This means that the agency that has comparative advantage because of the access to resources and factors of cheap production in return the agency that has method with more efficiency May be it to lose its competition power. In fact, have the relative advantage is necessary condition and have competitive advantage is sufficient condition for entry to global markets that each agency for successful presence in global markets should has both conditions together.

Comparative advantage is one of the economic theory in the field of international trade each country will be perch in a better position when that it produces the goods that it produces that more efficient than others and then exports these goods and in return imports the goods that it produces with less efficient. Taiyson (1993) knows the competitiveness ability in produce the goods and competitive services in international markets so that it create the standards of stable and growing life for citizenry simultaneouslywhile Paul Krugman (1994) knows the competitiveness as efficiency.

Among aims of this research are the provide concepts, theories and some methods of measuring competitiveness, study and measurement of aluminum industry competitiveness with the use of share shift analysis index with specify the share of each from its components and obtain the commercial position of Iran's aluminum export based on the commercial mapping index. The questions that also is provided in this research are as follows:

-How had been the process of share's aluminum export of Iran during the years of 2005 to 2014?

-Is competitive the aluminum industry in export the its products to the foreign markets?

-What position has assigned Iran to itself in the global markets according to the trade mapping position index?

- What is the appropriate strategies for the promotion of aluminum export of Iran?

-Also in this research, we evaluate the these two hypotheses:

- Aluminum industry of Iran is competitive in its products export.

- The competitive position of Iran in the aluminum industry is to improve during the period of 2014-2005.

The usual method in experimental studies with the use of two operational index of shift share analsisand trade mapping (TM) index hss been used in the practical section of research and calculation of competitive advantage of Iran in the aluminum export. The share shift analysis index estimates and measures as a criterion of determining competitiveness, difference between the actual change of a country's export (about a product and in a specific market) and change in whole export of that country as it changes consistent with global export.

The technique of share shift analysis (SSA) uses for a long time period of time that during of that economic structures can be change usually. Trade mapping index specifies the commercial position of Iran in the aluminum exports with the use of obtained results and it expresses that: 
- Is the global market of this product growing or not?

- Has been selected the suitable goods for export orientation?

Trade mapping index has been used for export performance analysis of goods groups by the international trade centre. A map or commercial plan compares the export growth with global demand growth. Basic foundation of these plans is same constant market share (CMS).

\section{Materials and Methods}

The criteria of determining comparative advantages can be defined in two ways mainly. A series of indexes are based on predictive data and second categories are based on retrospective data. Indexes based on predictive data, compare the cost of production before trade and prices and also other diverse combinatorial indexes based on potential, because they show the power of competition. On the other hand retrospective indexes show the main sources of advantage and in fact it proves the point of successful competition. In the field of retrospective indexes can be pointed to share shift analysis index and trade mapping index that they are used in this research.

\subsection{Share Shift Analysis Index}

The share shift analysis index estimates and measures as a criterion of determining competitiveness, difference between the actual change of a country's export (about a product and in a specific market) and change in whole export of country as it changes consistent with global export. This index of change in the global market share in the interval of 0 and $t$, is divided to three works of competitiveness, effect of reaction to change in global demand, (effect of adaptation) and structural effect against of the exports from a particular country and also structural effect is divided to two effects of initial geographic specialization and product specialization according to definition of international trade center.

Equation (1)

$$
\frac{\mathrm{x}_{\mathrm{i}}^{\mathrm{t}}}{\mathrm{x}_{\ldots .}^{\mathrm{t}}}=\sum \mathrm{j} \sum \mathrm{k} \frac{\mathrm{x}_{\mathrm{ijk}}^{\mathrm{t}}}{\mathrm{x}_{\mathrm{x}}^{\mathrm{t}}}=\sum \mathrm{j} \sum \mathrm{k} \frac{\mathrm{x}_{\mathrm{ijk}}^{\mathrm{t}}}{\mathrm{x}_{\mathrm{j} \mathrm{k}}^{\mathrm{t}}} * \frac{\mathrm{x}_{. \mathrm{jk}}^{\mathrm{t}}}{\mathrm{x}_{\mathrm{x}}^{\mathrm{t}}}
$$

Primary market is defined as a destination (j) for $k$ of product. Market share of $i$ country in the global market can be written as total of partner companies ( $\mathrm{j}$ markets) and also the goods (section $\mathrm{k}$ ) that have given weight in global export by these markets. Assuming that $x_{i}^{t}$ to be a value of $i$ country export to world in $t$ time and $x_{\ldots}^{t}$ to be value of world export in $t$ time in that case the export share of I country in the world is:

Equation (1)

Equation (2)

$$
\frac{x_{i}^{t}}{x_{\ldots .}^{t}}=\sum j \sum k \frac{x_{i j k}^{t}}{x_{\ldots . .}^{t}}=\sum j \sum k \frac{x_{i j k}^{t}}{x_{. j k}^{t}} * \frac{x_{. j k}^{t}}{x_{\ldots . .}^{t}}
$$

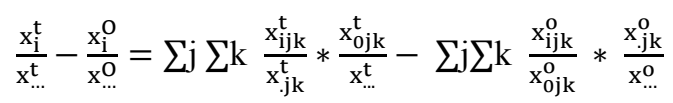

(the Source of expressed equations of 1 to 8 in this research, is international trade center)

Changing export share of the i country during the period of time is as equation (2):

Equation (2)

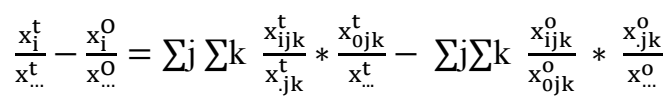

$x_{i j k}^{t}$ is value of $k$ goods of $i$ country export to the $j$ market in the $t$ time.

$\mathrm{x}_{\mathrm{ijk}}^{\mathrm{t}}$ is value of $\mathrm{k}$ goods of world export to the $\mathrm{j}$ market in the $\mathrm{t}$ time.

Competitiveness effect (CE): Improvement in market share is due to increase of competitiveness. This matter is calculated as change in the export share of country in the import of destination country market multiplied by primary share of partner country import in the global trade. This effect determines that factors except effect of the primary geographic expertise, effect of product expertise and effect of adaptation to what extent they can lead to increase or decrease of market share. This effect points to factors such as quick respond power of supply to demand, increase the quality of export goods.

Equation (3) 


$$
\mathrm{CE}_{\mathrm{ij}}=\sum \mathrm{j} \sum \mathrm{k}\left[\frac{\mathrm{x}_{\mathrm{jik}}^{\mathrm{t}}}{\mathrm{x}_{0 \mathrm{jk}}^{\mathrm{t}}}-\frac{\mathrm{x}_{\mathrm{ijk}}^{\mathrm{o}}}{\mathrm{x}_{0 \mathrm{jk}}^{\mathrm{o}}}\right] * \frac{\mathrm{x}_{0 \mathrm{jk}}^{\mathrm{o}}}{\mathrm{x}_{\ldots}^{\mathrm{o}}}
$$

In fact, this effect shows the growth rate different of an industry from the country with the similar industry from the world, if this effect to be positivein fact, it shows the market share of intended country should be improved compared to the market share of world and in relation to a common destination marketas a result, intended country has competitive advantage about intended goods compared to the world. This effect is defined with the equation (3).

Equation (4)

$$
\mathrm{CE}_{\mathrm{ij}}=\sum \mathrm{j} \sum \mathrm{k}\left[\frac{\mathrm{x}_{\mathrm{ijk}}^{\mathrm{t}}}{\mathrm{x}_{0 \mathrm{jk}}^{\mathrm{t}}}-\frac{\mathrm{x}_{\mathrm{ijk}}^{\mathrm{o}}}{\mathrm{x}_{0 \mathrm{jk}}^{\mathrm{o}}}\right] * \frac{\mathrm{x}_{0 \mathrm{jk}}^{\mathrm{o}}}{\mathrm{x}_{\ldots}^{\mathrm{o}}}
$$

$$
\mathrm{SE}=\sum \mathrm{j} \sum \mathrm{k} \frac{\mathrm{x}_{\mathrm{ijk}}^{\mathrm{o}}}{\mathrm{x}_{0 \mathrm{jk}}^{\mathrm{o}}} *\left[\frac{\mathrm{x}_{. \mathrm{jk}}^{\mathrm{t}}}{\mathrm{x}_{\ldots . .}^{\mathrm{t}}}-\frac{\mathrm{x}_{\mathrm{jk}}^{\mathrm{o}}}{\mathrm{x}_{\ldots . .}^{\mathrm{o}}}\right]
$$

Structural effect (SE): Improvement in market share is due to increased of import market dynamism (K production and $\mathrm{J}$ import market) regardless of each difference in the market share of country in these markets. This matter is calculated as a primary market share of the exporter country in the partner countries multiplied by the change in the primary markets share in global trade. Positivity of this effect is sign of desirable import market and the products with demand. Structural effect is defined with the equation (4).

$$
\mathrm{SE}=\sum \mathrm{j} \sum \mathrm{k} \frac{\mathrm{x}_{\mathrm{ijk}}^{\mathrm{o}}}{\mathrm{x}_{0 \mathrm{jk}}^{\mathrm{o}}} *\left[\frac{\mathrm{x}_{\mathrm{jk}}^{\mathrm{t}}}{\mathrm{x}_{\mathrm{t}}^{\mathrm{t}}}-\frac{\mathrm{x}_{\mathrm{.jk}}^{\mathrm{o}}}{\mathrm{x}_{\mathrm{o}}^{\mathrm{o}}}\right]
$$

Reaction to change in the global demand (adaptation effect) (AE): Adaptation effect is obtained by calculate the change in the market share of the country (i) and change in primary market share of that country in global import. If, both changes to be positive $(+,+)$, it shows that during the period of study, the country (i) has experienced the increase in the its market share in dynamic primary markets. This matter is concluded that result of crossover change is positive.

Equation (5)

$$
\mathrm{AE}=\sum \mathrm{j} \sum \mathrm{k}\left[\frac{\mathrm{x}_{\mathrm{ijk}}^{\mathrm{t}}}{\mathrm{x}_{\mathrm{j} \mathrm{k}}^{\mathrm{t}}}-\frac{\mathrm{x}_{\mathrm{ijk}}^{\mathrm{o}}}{\mathrm{x}_{\mathrm{j} \mathrm{k}}^{\mathrm{o}}}\right] *\left[\frac{\mathrm{x}_{\mathrm{jk}}^{\mathrm{t}}}{\mathrm{x}_{\ldots . .}^{\mathrm{t}}}-\frac{\mathrm{x}_{\mathrm{j} \mathrm{j}}^{\mathrm{o}}}{\mathrm{x}_{\ldots . .}^{\mathrm{o}}}\right]
$$

If, both changes to be negative (-, -), it shows that during the period of study, the country (i) has experienced the reduction in the its market share in subdominant primary markets, so the crossover chenge is positive once again and if that change in the global demand donot be in line with change in supply the export of one country this effect will be negative. This effect, consist of ability of export supply adaptation with change in global demand. Adaptation effect is defined with the equation (5).

Equation (5)

$$
\mathrm{AE}=\sum \mathrm{j} \sum \mathrm{k}\left[\frac{\mathrm{x}_{\mathrm{ijk}}^{\mathrm{t}}}{\mathrm{x}_{\mathrm{j} \mathrm{jk}}^{\mathrm{t}}}-\frac{\mathrm{x}_{\mathrm{ijk}}^{\mathrm{o}}}{\mathrm{x}_{\mathrm{j} \mathrm{j} \mathrm{o}}^{\mathrm{o}}}\right] *\left[\frac{\mathrm{x}_{\mathrm{jk \textrm {k }}}^{\mathrm{t}}}{\mathrm{x}_{\ldots}^{\mathrm{t}}}-\frac{\mathrm{x}_{\mathrm{j} \mathrm{jk}}^{\mathrm{o}}}{\mathrm{x}_{\ldots . .}^{\mathrm{o}}}\right]
$$

Equation (6)

$$
\mathrm{SGE}=\sum_{\mathrm{j}} \frac{\mathrm{x}_{\mathrm{ij} 0}^{\mathrm{o}}}{\mathrm{x}_{\mathrm{j} . \mathrm{j}}^{\mathrm{o}}} *\left[\frac{\mathrm{x}_{. \mathrm{j}}^{\mathrm{t}}}{\mathrm{x}_{\ldots}^{\mathrm{t}}}-\frac{\mathrm{x}_{\mathrm{j}}^{\mathrm{o}}}{\mathrm{x}_{\ldots}^{\mathrm{o}}}\right]
$$

The effect of the primary geographic expertise (SGE): This effect consist of the interests related to primary expertise's export of one country in the dynamic markets. In general, this matter is calculated as primary market share of the exporter country in the partner countries multiplied by the change in the share of partner countries in global trade. If the country has a good position in the markets of importer country this effect will be positive. This effect is defined in equation (6).

Equation (6)

$$
\mathrm{SGE}=\sum_{\mathrm{j}} \frac{\mathrm{x}_{\mathrm{ij} 0}^{\mathrm{o}}}{\mathrm{X}_{\mathrm{j} . \mathrm{j}}^{\mathrm{o}}} *\left[\frac{\mathrm{x}_{\mathrm{j} .}^{\mathrm{t}}}{\mathrm{X}_{\ldots}^{\mathrm{t}}}-\frac{\mathrm{x}_{\mathrm{j} . \mathrm{j}}^{\mathrm{o}}}{\mathrm{x}_{\ldots}^{\mathrm{o}}}\right]
$$


Equation (7)

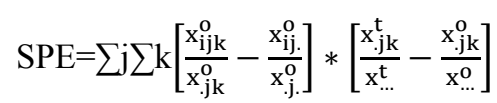

Effect of product expertise (SPE): This effect is related to supply of products that they face with the demand of dynamism. In general, this matter is calculated as change in primary market share in the global trade multiplied by difference between the primary share of exporter country in the primary markets and primary market share of the exporter country in the destination markets. This effect is defined in equation (7).

Equation (7)

$$
\mathrm{SPE}=\sum \mathrm{j} \sum \mathrm{k}\left[\frac{\mathrm{x}_{\mathrm{ijk}}^{\mathrm{o}}}{\mathrm{x}_{\mathrm{j} \mathrm{jk}}^{\mathrm{o}}}-\frac{\mathrm{x}_{\mathrm{ij}}^{\mathrm{o}}}{\mathrm{x}_{\mathrm{j} . \mathrm{j} .}^{\mathrm{o}}}\right] *\left[\frac{\mathrm{x}_{\mathrm{jk}}^{\mathrm{t}}}{\mathrm{x}_{\mathrm{t.}}^{\mathrm{t}}}-\frac{\mathrm{x}_{\mathrm{j} \mathrm{k}}^{\mathrm{o}}}{\mathrm{x}_{\mathrm{o}}^{\mathrm{o}}}\right]
$$

Equation (8)

$$
\frac{x_{i}^{t}}{x^{t}}-\frac{x_{i}^{o}}{x^{0}}=C E+S G E+S P E+A E
$$

Overall rating of change in market share is calculated like the simple average from the ratings for four following effect: competitiveness, primary geography expertise, product expertise and reaction to change in the global demand. Equation (8) is one of the formulas of studied pattern that it is used for calculate the competitiveness of countries each year by the international trade center.

Equation (8)

\subsection{Trade Mapping Index}

$$
\frac{x_{i}^{t}}{x^{t}}-\frac{x_{i}^{o}}{x^{0}}=C E+S G E+S P E+A E
$$

The index compares the growth of good i exports in the $\mathrm{J}$ country with growth of global import of i same product. Goods groups dynamically in the international trade center has been used for export performance analysis. This index compares the growth of good $\mathrm{i}$ exports by $\mathrm{j}\left(\delta_{\mathrm{ij}}\right)$ country with growth of global import of (ri) same productand growth of all global import (r). According to this index, if:

Amount of growth's import of good i to be more (less) than amount of growth's all global import, market of this goods is reconnoitred to growing or wane. If the growth amount of export of good $i$ in the $j$ country to be more (less) than growth amount of imports of this good, studied country will be winner (loser) in the intended goods export.

Table 1.

\begin{tabular}{cc}
\hline Characteristics of each quarter & \\
\hline$\delta \mathrm{ij}>r \mathrm{i}>r$ & First quarter winner in growing market \\
\hline$\delta \mathrm{ij}<r \mathrm{i}, \quad r \mathrm{i}>r$ & Second quarter: loser in growing market \\
\hline$\delta \mathrm{ij}<r \mathrm{i}<r$ & Third quarter: loser in declining market. \\
\hline$\delta \mathrm{ij}>r \mathrm{i}, \quad r \mathrm{i}<r$ & Fourth quarter: winner in declining market. \\
\hline
\end{tabular}

Source: International Trade Center

\section{Results}

For conducting calculation ofresearch, the majority of export and production data have been collected from the Customs of Islamic Republic of Iran and the International Trade Centre from countries around the world. We processed the data in Excel software by using index of analysis of share transfer and the index of business map to achieve correct analysis about the state of competitiveness of the aluminum industry in Iran. It should be noted the substantial limitation of this study, had been minor differences in some of the statistics from local 
organizations in Iran and international. Statistical population of this study in terms of product includes aluminum products and geographical scope of the research. It should be noted that how to choose the countries in the world is basis of this fact that countries that export value of iran to them had been more than $10,000 \$$ and at least five periods in Iran's exports had been as aimed country, have been included in the calculations. A total of 35 countries were selected considering the conditions listed.

\subsection{Value and Volume of Iran Aluminum Export}

- Export value: Table 2 shows value of the country aluminum export during time period of 2005 to 2014 . This value shows a growth of over $50 \%$ from 2005 to 2014 .

Table 2. Value of Iran aluminum export from 2005 to 2014

\begin{tabular}{|c|c|c|}
\hline \multicolumn{2}{|c|}{76} & $\begin{array}{c}\text { ISIC Code (International Standard Industrial } \\
\text { Classification) }\end{array}$ \\
\hline \multicolumn{2}{|c|}{ Aluminum } & $\begin{array}{c}\text { Description } \\
\end{array}$ \\
\hline $\begin{array}{l}\text { Period share } \\
\text { (percent) }\end{array}$ & $\begin{array}{c}\text { Export value (million } \\
\text { dollars) }\end{array}$ & Year \\
\hline 7.7 & 252.9 & 2005 \\
\hline 7.6 & 249.9 & 2006 \\
\hline 5.9 & 191.5 & 2007 \\
\hline 10.4 & 340.1 & 2008 \\
\hline 7.07 & 230.3 & 2009 \\
\hline 11.1 & 364.04 & 2010 \\
\hline 15.3 & 499.8 & 2011 \\
\hline 10.7 & 346.9 & 2012 \\
\hline 11.8 & 385.3 & 2013 \\
\hline 12.05 & 392.1 & 2014 \\
\hline 100 & 3253.3 & Total of peiod \\
\hline
\end{tabular}

Source: Customs Organization of Islamic Republic of Iran

- Export volume: Export volume of this commodity in Iran country had been over than 145505 tons in 2005. This volume has become equal to 202012 tons with growth of about $38 \%$ in 2014 .

\subsection{Measuring Competition Power of Aluminum Industry in Iran Country by Using Share Transfer Analysis} Index

4.2.1 Share Transfer Analysis Index: As it was stated, share transfer analysis index has been constitutes of three components of competitiveness effect, structural effect, and effect of reaction to change in global demand (adaption effect). Structural effect itself consists of two primary geographic specialty and product specialty effects. Year of 2005 has been considered as a base year in indices' calculations. Calculations of the other years are performed compared to this year.

4.2.2 Calculation of Competitiveness Effect: The calculations' results on competitiveness effect have been shown in Table 3.

It is observed that competitiveness effect in all the studied years is negative. This means that Iran does not have a comparative advantage in aluminum export. The country's competitiveness had regressed compared to global exports. 2007 is the worst year in this regard. The negative value of this effect in 2011 is less than other years.

The results show that Iran market share has not improved compared to the global market share and in relation to the common destination markets (35 markets in selected countries). In fact, Iran country according to the definition of competitiveness effect had not been with an appropriate competitiveness effect in exporting this group of products to target markets in these years compared to competitors in terms of relative prices, and difference in productivity between domestic and foreign manufacturers, ability to respond quickly to customers, difference in marketing efficiency, export and financing compared to the competitors.

4.2.3 Calculation of Structural Effect: Structural effect evaluates dynamism of import markets (product production and import markets) regardless of any difference in the country market share in these markets. Structural work consists of two primary geographic specialty and product specialty effects. The results of each of these effects have been shown separately in Table 3 . 


\subsubsection{Calculation of Primary Geographic Specialty Effect}

We find according to the results achieved from the research calculations that Iran has been with positive primary geographic specialty effect in the rest of the studied years except in 2006. The positivity of this effect in most years indicates that Iran export is towards goods that their growth rate is faster than the growth rate of global trade. Accordingly, Iran has a good position in the selected export markets. It has helped to its improvement during the period. In fact its share has increased in import countries.

\subsubsection{Calculation of Product Specialty Effect}

As seen, product specialty effect is positive in all the studied years. But its movement process is not in a regular way.

This result indicates that Iran in aluminum and its artifacts group have had export to the markets that have been with faster relative growth compared to other markets. The demand had been increasing for the products that previously had been with a growing demand.

\subsubsection{Calculation of Reaction to Change of Global Demand Effect (Adaption Effect)}

Reaction to change of global demand effect is negative in all the studied years according to the conducted calculations. This effect regularly had been with a downward trend until 2009. It was then improved slightly in 2008 and 2009.

These negative numbers and results suggest that Iran aluminum was not been able to increase its export share in global markets with increasing global demand. Also, it has not significantly reduced the amount of its supply with decline in global demand. In fact, Iran was not been able to be a good supplier in the market due to the overall increase in global demand.

\subsubsection{Resultant of Quad Effects of Share Transfer Analysis Index}

Resultant of the quad effects has become positive in the other years except in 2006 according to the calculations of quad effects and the sum of these four effects that their results have been shown in Table 3. It is totally seen two competitiveness and adaption effects had been negative in all the years. But two primary geographic specialty and product specialty effects had been positive almost in all the years. Primary geographic specialty effect has been with the most effect on the resultant of the effects. Accordingly, structural effect which consists of two parts of primary geographic specialty effect and product specialty effect is totally positive in all the years.

Table 3. Factors affecting the change of Iran market share in aluminum industry market during the studied time period

\begin{tabular}{cccccc}
\hline \multirow{2}{*}{$\begin{array}{c}\text { Sum of } \\
\text { effects }\end{array}$} & $\begin{array}{c}\text { Product specialty } \\
\text { effect (SPE) }\end{array}$ & $\begin{array}{c}\text { Primary geographic } \\
\text { specialty effect (SGE) }\end{array}$ & $\begin{array}{c}\text { Competitiveness } \\
\text { effect (CE) }\end{array}$ & $\begin{array}{c}\text { Adaption } \\
\text { effect (AE) }\end{array}$ & Year \\
\hline-0.072 & 0.030 & -0.028 & -0.063 & -0.011 & 2006 \\
0.305 & 0.043 & 0.420 & -0.121 & -0.036 & 2007 \\
1.415 & 0.099 & 1.460 & -0.066 & -0.077 & 2008 \\
2.208 & 0.093 & 2.289 & -0.063 & -0.110 & 2009 \\
2.238 & 0.069 & 2.357 & -0.024 & -0.073 & 2010 \\
2.560 & 0.058 & 2.548 & -0.002 & -0.044 & 2011 \\
2.853 & 0.242 & 2.788 & -0.044 & -0.132 & 2012 \\
3.249 & 0.069 & 3.299 & -0.080 & -0.037 & 2013 \\
3.073 & 0.094 & 3.128 & -0.113 & -0.035 & 2014 \\
\hline
\end{tabular}

(The numbers are multiplied by 10000 for ease of reading)

Iran country averagely has a competitive advantage of $1.9(0.00019 * 10,000)$ during the studied period according to the calculations conducted in the research. Primary geographic specialty has been with the most positive effect on this figure. Competitive effect has been with the most negative effect on this figure. It is obvious that competitive advantage is positive in all the years except in 2006.

Iran aluminum export share from total aluminum export in the world is equal to: $(0.24)-(0.18)-(0.12)$ - $(0.20)$ $(0.20)-(0.24)-(0.28)-(0.21)-(0.23)-(0.22)$ in terms of percentage, respectively from 2005 to 2014 according to the statistics of Center of International Trade and Iran Customs. 


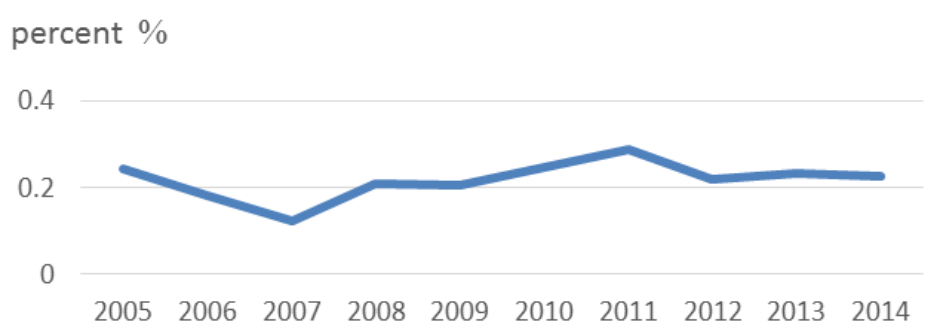

Figure 1. Iran country aluminum export share from total aluminum export in the world

UAE, Iraq, India, China and Afghanistan countries had been with the most competitive advantage in Iran country export during the studied period. The least competitive advantage is related to Kuwait, Italy, Germany, Japan and France countries. The most export of Iran country had been to UAE, India, Iraq, Taiwan, Turkey, Malaysia, Afghanistan and China countries during the studied period.

\subsection{Finding Commercial Position of Iran Country in Aluminum Industry by Using Trade Mapping Index}

This index compares growth of commodity (i) export by country $\mathrm{j}$ with global import growth of the same commodity (ri) and total global import growth (r).

Position of the country is obtained based on the trade mapping index in different years by obtaining import and export data and calculating their growth rate and comparing three parameters mentioned above. Its results have been shown in Table 4 .

Table 4. Iran commercial position in terms of trade mapping index in the studied interval

\begin{tabular}{ccccc}
\hline Commercial position & r & ri & sij & Year \\
\hline Loser in growing market & 15.45 & 31.26 & -1.2 & 2006 \\
Loser in declining market & 15.05 & 14.42 & -23.35 & 2007 \\
Winner in declining market & 15.96 & 1.02 & 77.56 & 2008 \\
Loser in declining market & -22.99 & -31.17 & -32.29 & 2009 \\
Winner in growing market & 21.09 & 30.25 & 58.05 & 2010 \\
Winner in growing market & 19.6 & 20.03 & 37.31 & 2011 \\
Loser in declining market & -0.01 & -8.7 & -30.58 & 2012 \\
Winner in declining market & 1.96 & 0.94 & 11.05 & 2013 \\
Loser in growing market & 0.84 & 7.92 & 1.76 & 2014 \\
\hline
\end{tabular}

Iran country had been loser in 2006, 2007, 2009, 2012, and 2014 according to the obtained results. This means that this country aluminum export growth had been lower than global aluminum import growth. It had been winner in 2008, 2010, 2011, and 2013. This being winner sometimes had been in the growing market and sometimes in the declining market.

So that this country had been winner in the growing market only in 2010 and 2011. Iran had been winner in the market in 2008, 2010, 2011, and 2013. This means that it has obtained larger share from the market. This position had been in the growing market means in the best mode only in 2010 and 2011. This position had been obtained in declining market in 2008 and 2013. This means that the declining market had affected our export less than its global extent.

\subsection{Evaluation of First Hypothesis}

If the first hypothesis is in this way that Iran aluminum industry is competitive in its products export in the studied time period. The results suggest that totally the country aluminum industry has a competitive advantage and is competitive in its export. Primary geographic specialty effect has the most positive effect in sum of the effects. This suggests that export combination of our country is towards goods that their export rate is faster than global export growth rate. 


\subsection{Evaluation of Second Hypothesis}

The second hypothesis is in this way that Iran competitive position in aluminum industry is improving during time period of 2014- 2005 AD. We see according to the results achieved from trade mapping index that commercial position of the country in this field had generally encountered with fluctuations, especially in some years.

But we find by further comparison of the numbers of Iran aluminum export growth with global import that even though we had been loser in most years, but the results are almost improving. In fact the distance of global import growth with our export growth is almost decreasing. In addition, the results extracted from share transfer analysis index showed that generally Iran almost is growing in terms of competitiveness despite some deficiencies in some performances.

It can reach to an appropriate competitiveness at the region level and global level by removing some of the obstacles, planning in order to use new technologies and market development and so on. Therefore, it can be said that the second hypothesis is also confirmed generally.

\section{Conclusion}

According to the obteined results from the share shift analysis index during the studied period, total and on average number +0.00019 is appeared for competitiveness annual. Although this number, is a small number but this shows the competitiveness capability of this industry in export of its products to global markets and also according to the obtained results from trade mapping index in 2006, 2007, 2009, 2012 and 2014, we were loser in the market of aluminum industry export this means that growth of aluminum export in our country had been less than growth of global import of aluminum but in 2008, 2010, 2011 and 2013 we were winner. In all the studied years with the use of trade mapping index index can be said more or less growth distance of our country export has been less with growth of global import that this can be a good sign for the development of aluminum industry in Iran.

- Factors such as sanctions of Western countries against Iran country, global recession in basic goods, considered high costs in order to export goods by Customs Organization, incomplete implementation of payment of energy subsidy to the production sector, including electricity energy, shortage of raw materials and its provision with the price higher than other countries have been with disproportionate effect on export of aluminum and its artifacts in Iran country in recent years.

- Attention of policy makers and exporters should be to increase their market share in the international arena due to this fact that the competitiveness effect is negative in all the years during the studied period. They should pay attention to factors such as supply to demand quick response power, increasing the quality of export goods, cost and so on to increase their share in these markets.

Accordingly, they can achieve these factors by reviewing the methods of production and improvement of production technologies, attracting domestic and foreign investment, research and development, proficient work force, etc., they can formulate and implement their programs and strategies in the coming years to improve competitiveness effect.

- High concentration in export markets causes the export industry vulnerability. Therefore, market expansion should be considered. While the main export of Iran country has been mostly focused on specific markets, the necessity of market expansion, appropriate marketing, and creating updated and efficient database are needed to identify the target markets.

\section{References}

Amit, R., \& Schoemakher, P. J. H. (1993). Strategic intents and organization rents. Strategic Management Journal(14), 33-46.

Cheng, F., \& Behin, J. C. (2000). Food Self-Sufficiency, Comparative Advantage, and Agricultural Trade: A Policy Analysis Matrix for Chinese Agriculture. Working Paper, 99-223.

Competitiveness Advisory Group. (1995a). Enhancing European Competitivenes. First Report to the President of the Commission, the Prime Ministers and the Heads of State.

Competitiveness Advisory Group. (1995b). Enhancing European Competitiveness. Second report to the President of the Commission, the Prime Ministers and the Heads of State.

Gonzales, L., Kasrino, A. K., Peres, N. D., \& Rosegrant, M. W. (1993). Economic Incentives and Comparative Advantage in Indonesian Food Production. Research Report, 93. International Food Policy Research 
Institute, Washington D. C.

International Trade Center. (2007). The Trade Performance Index: Technical Notes. International Trade Center (ITC), Market Analysis Section. Geneva, Switzerland.

Man, T. W. Y., Lau, T., \& Chan, K. F. (2002). The Competitiveness of Small and Medium Enterprises A Conceptualization with Focus on Entrepreneurial Competencies. Journal of Business Venturing, 17, 123-142.

Michael, E. P. (1990). The Competetive Advantage of Natios. Free Press, New York.

Michael, E. P. (1990). The Competetive Advantage of Natios. Free Press, New York.

Nik, M. N. M., \& Haslina, C. Y. (2008). Export Competitiveness of Malaysian Electrical and Electronic (E\&E) Product: Comparative Study of China, Indonesia and Thailand. International Journal of Business and management, 3(7), 65-75.

Porter, M. E. (1990). The Competitive Advantage of Nations. Harvard Business Review, 74 -91.

Quazi, S., \& Dorosh, P. (2002). Comparative Advantage in Bangladesh Crop Production. Mssd Discussion Paper, 47. International Food Policy Research Institute.

Ramona, F., \& Ornella, K. (2006). Sugar Sector in Croatia: Competitive or Not. 98th Eaae Seminar, Marketing Dynamic within the Global Trading System: New Perspectives, Chaina, Crete Greece as in: 29 June - 2 July, 2006.

Robertas, J., \& Egidijus, R. (2010). Competitiveness of Lithuanian Textile and Clothing Industry. 6th International Scientific Conference May 13-14, 2010, Vilnius, Lithuania. Business and Management 2010 Selected Papers. Vilinius, Lithuania.

Welch, J. M., \& Conrad, P. L. (2007). Measuring Competition for Textiles: Does the United States Make the Grade. International Food and Agribusiness Management Review, 10(4), 64-78.

\section{Copyrights}

Copyright for this article is retained by the author(s), with first publication rights granted to the journal.

This is an open-access article distributed under the terms and conditions of the Creative Commons Attribution license (http://creativecommons.org/licenses/by/4.0/). 